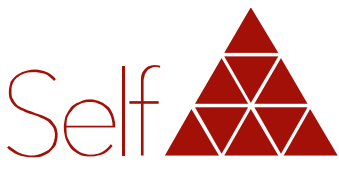

Revista do Instituto Junguiano de Săo Paulo

\title{
Reflexões sobre o método de Nise da Silveira
}

\author{
Reflections on the method of Nise da Silveira \\ Reflexiones sobre el método de Nise da Silveira
}

\author{
Cristiane ADAMO \\ Denis Canal MENDES \\ Irene GAETA \\ Paola VERGUEIRO \\ Paula DARÉ \\ Patrícia CAMPOS \\ Silvana PARISI
}

Entrevista realizada com Franklin Chang, analista junguiano com formação no Instituto C.G. Jung de Zurique, Suíça, membro da International Association for Analytical Psychology - IAAP e orientador de grupos de estudo sobre taoísmo, alquimia chinesa e psicologia junguiana. Chang também foi diretor da Casa das Palmeiras de 1997 a 2001, um dos cenários do trabalho de Nise da Silveira, renomada psiquiatra brasileira, que transformou o tratamento e a relação entre os pacientes e os médicos e profissionais com atuação em hospitais psiquiátricos. Nise defendeu a arte como instrumento terapêutico e liberador da criatividade. A partir de seu empenho, foi criado o Museu de Imagens do Inconsciente, no Rio de Janeiro. Pela relevância e ineditismo, seu trabalho impressionou colegas, artistas, críicos de arte e, também, a C.G. Jung, com quem passou a se corresponder com regularidade. Na entrevista, realizada por integrantes do Departamento de Arte e Psicologia da Associação Junguiana do Brasil - AJB e do Núcleo de

Conflito de interesses:

Entrevistado e entrevistadores declaram não haver nenhum interesse profissional ou pessoal que possa gerar conflito de interesses em relação a esta entrevista. de Arte e Psicologia Analítica do Instituto Junguiano de São Paulo NAPA/IJUSP, Chang relembra da convivência, do aprendizado e da troca de experiências com Nise da Silveira. Chang também destaca os pioneiros do movimento junguiano em São Paulo como Leon Bonaventure e Petho Sandor, com quem participou de grupos de estudo; os contatos com sua orientadora, Marie-Louise von Franz, e com colegas que estudavam a filosofia e religiões orientais, como Heinrich Robert Zimmer, que utilizava a mandala como elemento terapêutico, citando como exemplo o trabalho da psicologia e alquimia na sequência de sonhos do Wolfgang Ernst Pauli.

O vídeo com trecho da entrevista pode ser acessado na página principal do site (https://self.ijusp.org.br/self/index), clicando na caixa do arquivo WMV. 
Núcleo de Arte e Psicologia Analítica do Instituto Junguiano de São Paulo NAPA: Compartilhe conosco sua experiência. Como foi sua formação em Zurique e seu encontro com Nise da Silveira?

CHANG: Bom, o meu primeiro contato com a doutora Nise foi o livro: "Jung, vida e obra" (Silveira, 1971). No começo eu fazia filosofia, na época, e desisti de filosofia por causa desse livro, porque achei que, realmente, Jung era a resposta de várias coisas que eu estava procurando. Isso foi na década de 1970. Quem era o movimento junguiano? Nós tínhamos o Leon [Bonaventure] e tínhamos o [Petho] Sandor, aqui em São Paulo, e ela lá, no Rio [de Janeiro]. Nas faculdades não tinha nada. Eu tinha que estudar por conta própria, então eu fui fazer o grupo de estudos do Leon aos domingos à tarde. Esse já era o primeiro teste para saber quem é que gostava mesmo de Jung. Se passaram outras coisas na minha vida e eu fui, aos poucos, saindo dessa área porque, paralelamente, eu fiz um curso de engenharia de minas. Depois, com casamento, filhos, eu fiquei muito ocupado com essa parte prática da vida. Dez anos mais ou menos se passaram, quando eu tinha 34, 35 anos, surgiu a possibilidade de ir a Zurique. Então, Zurique, 1985, foi um ano que eu tirei para mim, um ano sabático e o instituto [International Association for Analytical Psychology - IAAP], tem uma coisa muito boa, permite que você faça um ano como ouvinte e, caso você queira ser um trainee, um aluno regular, você pode fazer sua application e se candidatar. Então, depois de um ano eu resolvi ficar porque era aquilo que eu realmente queria. Lá eles têm um comitê de três pessoas que te acompanham o curso todo, então eu fiz essa entrevista com eles e ficou certo que eu ia fazer o curso regular. Levei cinco anos e meio para acabar porque nesse meio tempo também tive umas idas e vindas para o Brasil. Eu tive bons contatos, fiz análise com três pessoas e, por sorte, a minha orientadora foi a doutora [Marie-Louise] von Franz. Estudei algumas coisas sobre alquimia chinesa, ninguém entendia do assunto, ninguém queria ser meu orientador. Ela foi a única que se dispôs a me orientar. No dia da apresentação, foi coisa muito simples, uma mesa na casa dela, ela com os outros dois orientadores, e ela falou assim:

- Olha que interessante (ao primeiro analista), você estudou e se formou comigo na década de 1970, você Schwartzman, você foi a segunda, década de 1980, agora você é da década de 1990 e eu estou encerrando o meu ciclo.

Porque ela dizia que era uma tigresa desdentada. Então, uma tigresa desdentada não tem mais poder. E ela queria ir para o Instituto e morder umas pessoas, infelizmente, como ela não tinha dentes, escapavam dela esta era a doutora von Franz. Em uma dessas vindas [ao Brasil], em 1988, eu fui com a minha irmã visitar a doutora Nise pela primeira vez. A minha irmã, a Jerusa Chang, arquiteta, fez a monografia dela de conclusão de curso sobre um modelo de hospital psiquiátrico baseado na teoria junguiana. Foi um projeto que a doutora Nise orientou, um projeto interessantíssimo e elas ficaram muito amigas. Ela ia para o Rio e ficava lá 
no Engenho de Dentro [bairro da Zona Norte] e a doutora Nise a orientava. Em 1988 eu voltei e ela [irmã] me convidou:

- Vamos lá no Rio, visitar a doutora Nise? Eu soube que ela caiu, quebrou o quadril, está em uma cadeira de rodas.

E nós fomos ao Rio e, realmente, ela estava de cadeira de rodas e quando ela soube que eu estava [estudando] em Zurique, ela perguntou:

- Como é que está? $\mathrm{E}$ aquele pessoal? E a von Franz, o que ela está fazendo? Qual o projeto? $\bigcirc$ que está acontecendo lá?

Queria saber tudo de Zurique. Eu passei para ela o que eu sabia, o que eu conheci. Enfim, foi uma tarde que a gente ficou conversando de tudo, de psicologia, da vida, o acidente que ela teve, porque ela, em 1986, teve uma queda e fraturou o quadril e quiseram levá-la para $\circ$ hospital para ser operada. Ela falou:

- Não, eu não quero, prefiro ficar assim do que ir para o hospital.

Aqueles encontros eram mágicos; ficava sempre uma coisa pendente, alguma coisa que você de alguma forma espera que volte a acontecer. Então, quando eu voltei para o Brasil, em 1994, ela me convidou para ir para o Rio dar um curso lá na Casa das Palmeiras [instituição de reabilitação mental com atividades expressivas, terapias ocupacionais, em regime aberto, idealizada por Nise da Silveira] e eu disse assim:

- Como é esse curso que você quer?

Ela falou:

-Um curso que você fale sobre Jung.

Então, falei:

- Tudo bem, mas eu vou dar um curso baseado no seu livro ["Jung, vida e obra"].

Ela falou:

- Mas você não tem coisa melhor, não?

Respondi:

- Não, eu vou dar [o curso] sobre o seu livro porque eu acho que é muito importante e eu tenho uma relação especial com ele.

Ela concordou. Montamos um programa, era um curso de um semestre, eu ia de 15 em 15 dias, nós dividíamos o livro em vários capítulos, enfim. Já no ano seguinte [1995], estava havendo uma reestruturação na Casa das Palmeiras e ela me convidou para participar. Falei para ela que ia ser difícil porque minha vida estava em São Paulo, mas ela insistiu:

- Venha aqui quando você puder, como você quiser. 
Eu já estava meio seduzido, principalmente depois que eu conheci o arquivo de imagens da Casa. Eu percebi ali uma riqueza incrível. Porque o mesmo trabalho que ela fez no Museu [de Imagens do Inconsciente] fez na Casa das Palmeiras, então tinha arquivos enormes com séries de pinturas de doentes mentais e eu fiquei fascinado com aquilo: "isso aqui é ouro, pesquisar e continuar esse trabalho". Dei um jeito:

- "Olha, eu vou, mas eu vou dois dias por semana, está bom?

Só que, aos poucos, fui me envolvendo com o lugar e daqui a pouco eu era um diretor técnico e o Pedro Pellegrino era o diretor presidente. $\bigcirc$ Pedro era uma pessoa muito especial. Havia uma história que, [na] primeira vez que ele foi visitá-la, ele chegou:

- Prazer, doutora Nise.

Ela olhou para ele e disse:

- Você deve ser mais um engomadinho de Copacabana [bairro da Zona Sul da cidade].

Ele levou um susto:

- Eu? Não sou engomadinho de Copacabana coisa nenhuma.

Ela respondeu:

- Gostei.

Gostou dele. Porque ela gostava de testar as pessoas, entendeu? Jogava para ver como as pessoas reagiam. E ele teve uma reação totalmente espontânea, natural, que agradou a ela. Ele também foi trabalhar na Casa e logo tornou-se o presidente e eu era o diretor técnico. Mas ele, depois de um ano e pouco, adoeceu, e teve que se retirar, fazer um tratamento de urgência e no final veio a falecer. Logo depois ela me convocou:

- Agora é a sua vez.

- Minha vez do quê?

-Quero que você assuma a presidência da casa.

Falei:

-Não, doutora Nise, está ótimo, estou fazendo o que eu quero, a parte técnica, estudando, estou em contato com os clientes [como ela chamava os pacientes]; a parte administrativa não quero, não é para mim.

-Não tem jeito, tem que ser você.

Foi uma experiência! Claro, montei uma equipe... mas foi uma grande experiência. Foi uma coisa diferente. Você entra em uma instituição onde a parte técnica e a parte administrativa estão harmonizadas. $E$, sobretudo, o seguinte, a direção não é a parte financeira, comercial, nada disso, é a parte técnica porque eu coloquei na administração uma psicóloga, Vera Macedo, 
que, como eu, também não queria [aceitar o cargo], mas acabou fazendo. Isso é uma coisa muito importante. Muitas instituições sofrem exatamente dessa cisão. Uma das queixas que a doutora von Franz tinha do Instituto [IAAP] era isso, que a parte administrativa já estava cindida da parte técnica. Então, isso, evidentemente, provoca conflitos, provoca uma perda de qualidade. Enfim, foi esse período que se passou, um período muito rico porque nós fizemos muita coisa, sempre com o apoio dela [Nise], óbvio. Nós organizamos ciclos de palestras abertas para o público em geral, mas que envolviam também aspectos artísticos e criativos de várias áreas, não só a psicologia. Eu lembro, Frei Beto foi dar várias palestras, Leonardo Boff, Augusto Boal, tinham também artistas, cantores, uma gama de pessoas que passaram por lá e que, de certa forma, era uma contribuição deles para a Casa porque a gente passava o chapéu, arrecadava algum dinheiro e conseguia tocar. Logo que eu entrei ela procurou me esclarecer:

- Aqui, nós somos franciscanos, filosofia de São Francisco de Assis, procure ler sobre ele.

Com o tempo, eu vim a entender que, na realidade, o que ela prezava? Ela prezava, acima de tudo, a liberdade. Ela gostava de contar a seguinte história:

"-Era uma vez, um cachorro gordo que estava passeando e, de repente, ele encontrou um lobo magro, esfomeado, com o olho vidrado. Ele falou:

- Meu amigo, você está mal, não é?

- Eu não como há vários dias, eu estou mal mesmo.

- Você não come há vários dias? Eu como todo dia, lá em casa tem fartura, tem comida, bebida...

- Ah, é? Puxa vida, você podia me arrumar uma refeição.

- Claro, vamos lá em casa e você vai comer até se fartar.

O lobo acompanhou o cachorro, chegaram lá, o dono do cachorro chamou:

- Rex, vem cá.

Colocou a coleira no cachorro. Quando o lobo viu aquilo, pegou e deu no pé."

Essa a filosofia dela: antes ser um pobre esfomeado, mas livre, do que ser um gordo rico e preso. Essa foi sempre a filosofia, como a Casa sobreviveu e sobrevive até hoje. Graças às doações, graças a contribuições que as famílias dos clientes proporcionam... as famílias que podem, porque as que não podem também não contribuem, ninguém é discriminado porque paga ou porque não paga, isso é uma questão completamente secundária. Nós complementamos com essas coisas, cursos, palestras etc. Uma administração super enxuta. 
NAPA: Eu estive lá por um tempo e eu acho que muito se perdeu. Uma das questões é que a Nise nunca pertenceu a nada nem a ninguém. Pelo fato de não pertencer, no final, ela ficou sem ter alguém que ficasse à frente levando o trabalho dela, como ela fez. Ou você acha que esse trabalho permanece? As coisas continuam?

CHANG: Claro que existem altos e baixos. Mas, por exemplo, você tem que entender a Casa de uma outra maneira. A Casa não é uma instituição comum, a Casa das Palmeiras pertence aos clientes.

NAPA: Sim, mas quem é que conduz?

CHANG: Não interessa quem conduz. Interessa que eles vão lá. A grande diferença é essa. Enquanto as pessoas forem lá e frequentarem a Casa, ela vai ficar em pé. Não é porque existe uma estrutura que vá mantê-la em pé. É o contrário.

NAPA: Mas em termos de acolhimento, de atendimento?

CHANG: Eu não sei, eu saí de lá há algum tempo. Mas eu acho que [a] filosofia deve continuar, não é? Tanto que ela recusou patrocínios de várias instituições, Rede Globo, Johnson's. No final, depois que eu saí, eu soube que fizeram uma coisa terrível, aceitaram o patrocínio da Petrobras. Durou um ano e acabou.

NAPA: Mas isso sempre foi em nome do custo de não perder a liberdade?

CHANG: Exatamente.

NAPA: Eu queria entender um pouco melhor isso. A Casa das Palmeiras se mantém porque existem os clientes. Isso é verdade. Você vai lá agora, têm os clientes. Mas a condução do ateliê, por exemplo, como a Nise idealizou?

CHANG: Mas isso é óbvio que depende muito do ciclo. É como uma plantação, tem ciclos que você colhe mais e ciclos que você colhe menos, depende muito das equipes que vão se formar. Na realidade, existe um trabalho, muito importante, que é a formação de pessoas. Porque todo mundo que passa por lá e trabalha, muda a cabeça. Você para de se achar doutor, de se achar o "sabe-tudo" porque você é colocado em uma posição em que você tem que aprender. É isso que, no final, a doença mental ensina para a gente. Que nós não sabemos nada.

NAPA: Então, isso leva à pergunta: existe um método? E se [existe] você teria como descrever esse método?

CHANG: Existe e não existe. Como um ditado taoísta que diz assim: "o método certo, com uma pessoa errada, vai dar errado; o método errado com a pessoa certa, vai dar certo". O método não é o mais importante, é secundário, o importante é a qualidade das pessoas que estão lá. Se a qualidade daquelas pessoas que estiverem lá for capaz de se harmonizar com o ambiente, capaz de ter consciência do que está vendo.

NAPA: Mas isso não pode fazer parte do método? 
CHANG: É perigoso você falar método. Porque método pode significar também receita. É como o método Junguiano. Existe receita para a terapia junguiana? A teoria surgiu a partir das experiências, das vivências e da clínica dele [C. G. Jung]. Uma vez, um analista me disse o seguinte:

- Na realidade, a teoria existe para que nós nos comuniquemos, os terapeutas; para o cliente não interessa nada.

Então, nós precisamos de uma linguagem para nos comunicarmos. É a mesma coisa com a Nise. A Nise, por exemplo, desenvolveu alguns conceitos revolucionários, conceitos que não existiam em psiquiatria. Um deles, por exemplo, chama-se o afeto catalisador. $\bigcirc$ que é o afeto catalisador? $\bigcirc$ afeto catalisador é uma forma sutil de você estimular o trabalho criativo. Só que você não pode estimular o trabalho criativo no outro se você não está fazendo também. Então, o monitor, no ateliê de pintura, também pintava.

NAPA: Ao mesmo tempo?

CHANG: Ao mesmo tempo. Uma das coisas que ele fazia era também trabalhar. Por quê? Porque aí existia algo que é o princípio da imitação.

NAPA: É uma identificação.

CHANG: Exatamente. Não tem ninguém que fica de fora, olhando todos trabalhando como se fosse a autoridade ou acima das pessoas que estão trabalhando. Todos trabalham. Na filosofia de um método, em primeiro lugar, temos que falar de trabalho. Mas é um trabalho, evidentemente, sutil. Ninguém é obrigado a trabalhar. Você pode chegar, sentar, colocar uma folha branca, não sair nada e ir embora. Ninguém vai falar nada. Por quê? Porque não saiu. Não aconteceu naquele momento o trabalho. Mas acontece uma coisa interessante: mesmo que você não tenha produzido nada, nós dizemos assim: "Por favor, anote a data", e guardamos na pasta. A folha em branco significa alguma coisa. Então, se você olhar uma série, por exemplo, de imagens ao longo do tempo e, se tiver essas imagens brancas, você pode perceber algumas coisas, alguns padrões que, de repente, você pode relacionar. Então, é muito importante isso. Quando você pesquisa, você tem que considerar todos os aspectos. Todas as pessoas ali fazem parte, na verdade, de um trabalho contínuo de pesquisa.

NAPA: E as pessoas que chegavam ao ateliê escolhiam livremente o tipo da atividade ou tinha alguma espécie de direcionamento?

CHANG: Totalmente livre. Inclusive, tinham uns tão radicais que chegavam e olhavam: "Não. Hoje não". Viravam as costas e iam embora.

NAPA: Ficava aberto? A pessoa podia ficar o dia inteiro?

CHANG: Não, houve fases. Houve uma época em que a casa conseguiu se manter em dois períodos, de manhã e à tarde. Depois, por problema de estrutura, ficou mais o período da tarde. Então, era o seguinte: começava a uma [hora]. Da uma até as três, três e meia funcionavam os ateliês. Todos os 
ateliês funcionavam simultaneamente. Modelagem, pintura, papier-mâché, colagem, xilogravura e, às vezes, funcionava o de bordado e costura.

NAPA: Tinha música?

CHANG: Conforme o que ele [paciente] estivesse sentindo. Muitas vezes, as pessoas que estavam piores gostavam de trabalhar com barro. Pegavam aquele barro, amassavam, espancavam... e você já sabia: "aqui tem coisa". Se estivesse um pouco melhor, geralmente escolhia pintura, colagem. Algumas pessoas gostavam de fazer costura, bordados, tear. E quando a pessoa estava em uma fase melhor, muitas vezes escolhia trabalhar com madeira. Havia o ateliê de xilogravura. Então, essa primeira etapa era livre. A pessoa podia fazer um trabalho aqui, um lá...ou ficar o tempo todo num ateliê. Era uma coisa mais ou menos livre. Evidentemente que tudo isso era acompanhado e, de certa forma, registrado também.

NAPA: Acompanhado, você diz, pelos monitores?

CHANG: Pelos monitores. Cada ateliê tinha um monitor.

NAPA: Quantas pessoas em média em cada ateliê?

CHANG: De clientes?

NAPA: É, por ateliê?

CHANG: Teve uma época em que tínhamos 40 clientes. Dez, por exemplo, era o máximo de capacidade.

NAPA: Sabe o que me chamou a atenção, eu percebi que houve artistas que trabalharam na Casa e eu fiquei pensando: será que, de alguma maneira, esses artistas - não um monitor - faziam com que o paciente, o cliente, produzisse de modo diferente?

CHANG: Veja, aí depende muito também. A doutora Nise era uma pessoa, ela mesmo dizia, que era uma sedutora do bem. Ela tinha um grupo de estudos - isso também é muito importante. Eu vou fazer um parêntese agora e contar um pouco da história do grupo de estudos. Isso tem que ficar claro e ninguém deve nunca esquecer isso, na minha opinião. Vamos lembrar que foi ela [Nise] quem introduziu o Jung no Brasil. Foi a pessoa que, já em 1950, tinha um grupo de estudos do Jung lá no Rio.

NAPA: Antes do Leon [Bonaventure] e antes do [Petho] Sandor?

CHANG: Muito antes. E depois, em [19]55, ela oficializou o grupo de estudos. $\bigcirc$ grupo era aberto lá na casa dela, às quartas[-feiras], à noite. $E$ aparecia todo tipo de pessoa: artistas, jornalistas, filósofos, poetas... As pessoas iam estudando e ela ia sacando qual era a das pessoas. Se de repente ela tivesse uma intuição e dissesse: "não, aquela pessoa ali eu acho que vai dar certo", aí chegava e dizia:

- Você não quer ir lá na Casa Palmeiras conhecer e tal...

Na próxima etapa: 
- Você não quer passar um tempo aqui? Ver como funciona...

E daqui a pouco a pessoa mesmo se empolgava e ficava. Então, realmente muitos artistas passaram por lá. Ou se não passaram por lá, tinham conexão com o trabalho de lá. Por exemplo, um diretor de teatro que faleceu recentemente, o Fauzi Arap, que escreveu o livro "Mare Nostrum", onde conta a experiência dele lá na Casa Palmeiras. O Fauzi era monitor do teatro lá e vivia sendo assediado porque ele era um fumante. Um dia ele se cansou, na época a Maria Betânia estava estreando. Ela tinha chegado no Rio e ele dirigiu o show "Rosa dos Ventos". Ele falou:

- Olha, se eu ganhar dinheiro com esse show nunca mais vai faltar cigarro para vocês.

Todo mundo aplaudia ele. E "Rosa dos Ventos" estourou. Ficou anos em cartaz no Rio e em São Paulo.

NAPA: Ele cumpriu a promessa?

CHANG: Cumpriu. $\bigcirc$ primeiro dinheiro que ele recebeu, ele chegou com pacotes de cigarro para todos e disse:

- Hoje ninguém me pede cigarro. É de todos.

Era um dia de festa, fartura de cigarro. Então, era assim, pessoas que tinham um contato direto. Outros, indireto. Por exemplo, o Ivan Serpa. Ele não chegou a trabalhar lá na Casa, mas tinha um pintor, um cara que era um doente mental, e era um artista. $\bigcirc$ cara realmente fez umas pinturas geniais. Se chama Darcílio Lima. Teve uma exposição dele no Rio, não sei se aqui em São Paulo. E ele tinha realmente um dom, o Ivan o apadrinhou. Ivan ia no ateliê, ensinava umas técnicas, uma coisa mais específica... o que era muito bom. O Darcílio Lima chegou a expor na Europa.

NAPA: Já o vi falando sobre a experiência dele [Darcílio] na Casa. Ele se emociona até hoje quando fala.

CHANG: O Darcílio, para vocês terem uma ideia de como a vida às vezes é cruel, ele veio de uma cidade do interior, se não me engano do Ceará. Chegou a ser um famoso artista internacional e quando voltou para cidade dele achando que ia se estabelecer, teve um surto e foi enjaulado. $\mathrm{Na}$ própria cidade natal. Era assim. Antigamente as pessoas do interior, principalmente, achavam que a doença mental era uma coisa perigosíssima. Então, enjaulavam, interditavam. Lá no [hospital psiquiátrico] Pedro II mesmo, ainda tinha um resquício na década de [19]40, de jaulas onde as pessoas ficavam. Bom, mas então voltando um pouco à doutora. Ela tinha isso de captar pessoas. Tinha um carisma incrível e ela captava as pessoas mais ou menos para certos trabalhos em que ela achava que ia dar uma conjunção. E com isso é que ela foi, de certa forma, conduzindo a Casa, o museu, o grupo de estudos... tudo em paralelo. Uma coisa alimentava a outra, entende? Não eram coisas separadas. Mas, então, recentemente em São Paulo... Alguém foi ver a [exposição] "Ocupação Nise"? 
NAPA: Fomos.

CHANG: Vocês viram uma coisa histórica. $\bigcirc$ famoso encontro da Nise com o Jung. Nesse encontro o Jung indicou a doutora [Marie-Louise] von Franz para ser a terapeuta dela. A partir daí desenvolveu-se uma relação muito forte das duas. Ela ficou sendo uma espécie de mentora. Quando ela acabou de escrever esse livro "Imagens do inconsciente", ela tinha um certo receio se esse livro estaria tecnicamente bom. E aí ela mandou uma cópia para a von Franz, perguntando qual era a opinião dela. A resposta foi: "Publique", ponto.

NAPA: Mas ela mandou em português? Porque ela lia latim...

CHANG: Ela era poliglota. Lia em várias e várias línguas. E foi assim que ela adquiriu a coragem, depois, para lançar o segundo também, "O mundo das imagens". Fazia parte também do grupo de estudos a "Revista Quaterno". Ela achava que as pessoas deviam sempre escrever. Particularmente, nós, junguianos, temos uma dificuldade para escrever, porque nós preferimos muitas vezes ficar no plano das ideias. E é difícil escrever. Mas ela achava que era importante. Então, as pessoas do grupo de estudo ela incentivava a escrever também. Ela escolhia um tema, e a ideia seria lançar uma revista de tempos em tempos com um determinado tema. Por exemplo: meninos de rua.

NAPA: Temas do cotidiano?

CHANG: Temas do Brasil, mais do que do cotidiano. Temas brasileiros - "A farra do boi". Então, incentivava as pessoas a pesquisar a farra do boi:

- Vamos pesquisar, por exemplo, em outras culturas como é a relação do homem com o touro, com o boi...

Aí vai na Índia, Grécia, outras culturas, e que rituais existem e tal. Por quê? Porque no fundo ela odiava essa coisa da farra do boi. Ela achava que nós tínhamos que nos conscientizar dessa necessidade de mudança dessa mentalidade. Então, a revista com a farra do boi foi nessa direção. Eu, quando entrei, já de cara ganhei esse encargo. Porque em [19]96 a doutora von Franz faleceu e ela queria prestar uma homenagem.

Ela disse para mim organizar essa "Revista Quaterno". Era a número sete. Peguei um depoimento daqui, dali, de algumas pessoas e tal e aí chegou o grande momento:

- Doutora, e o seu trabalho?

- Não, eu não estou preparada. Eu não tenho condições de escrever sobre ela.

- Mas a revista... não foi a senhora que sugeriu que fizéssemos uma revista em homenagem a ela?

Mas ela não quis escrever. Não sei se emoção... não sei. Alguma coisa de caráter íntimo que ela não quis revelar. Eu senti isso, então também não 
insisti demais. Saiu a revista, o número sete. Mal sabia eu que a revista número oito seria em homenagem a ela. Um trabalho que me levou dois anos coordenando...não sei se alguém já viu a "Quaterno" número oito, em homenagem a Nise Silveira. Toda semana tinha uma reunião. Mas, enfim, fizemos. De certa forma, esse trabalho foi para mim uma homenagem pessoal a ela. Porque eu a considero uma mestra. Eu vim de uma cultura chinesa que diz o seguinte: os pais nos dão a vida, mas os mestres nos ensinam o significado dela. Por isso que temos que valorizar muito quem ensina. Realmente com quem nós aprendemos. E ela - olha que interessante - chamava o Jung de mestre. Não chamava de doutor, nem professor. Ela o chamava de mestre e a doutora Franz de mestra. Eu percebi isso, que era uma conexão também com um aspecto oriental. E até, parando agora para pensar um pouquinho, é difícil escrever principalmente sobre uma pessoa que foi tão importante para você. Por isso que eu entendo como deve ter sido difícil para ela, logo depois da morte, escrever sobre uma pessoa que tinha sido tão importante.

NAPA: Sempre é pouco.

CHANG: Exatamente.

NAPA: Aproveitando esse momento de emoção: tem alguma coisa que te tocou profundamente que você vivenciou e que poderia compartilhar com a gente? Na Casa Palmeiras, na relação com a Nise... algum momento muito especial?

CHANG: A doutora Nise tinha vários aspectos. Como toda personalidade profunda, ela é multifacetada. Mas não no sentido doentio; ela é multifacetada no sentido da riqueza, da complexidade de ter vários aspectos que estão conectados entre si por uma espécie de eixo. Então, ela, por exemplo, tinha um grande amor pelos animais. E ela tinha gatos, você ia visitá-la e estava ela e o gato. Aí você olhava para ela, ela olhava para o gato, você olhava para o gato, o gato olhava para ela...ficava um jogo ali muito sutil de interação. Então, isso eu estou falando para entrar no afeto catalizador. $\bigcirc$ que é um afeto catalizador. Por exemplo, o caso da Delina, que é o seguinte: era uma mulher que não falava nada com ninguém, mas a doutora tinha sempre esse hábito de cumprimentar um por um pelo nome. Ela falava:

- Bom dia, Delina.

Dez anos falando:

-Bom dia, Delina.

Um dia:

- Bom dia, Delina.

Vai em frente e ela:

- Bom dia, doutora. 
Algo aconteceu. Começou o processo de cura aí. Delina começou a conseguir falar dela com outras pessoas... até se apaixonou por um outro, o Carlos Pertuis. Em resumo, era isso. Então, vocês vejam: o afeto catalisador é essa coisa sutil, mas profundamente humana de você reconhecer o outro. De falar, cumprimentar, olhar nos olhos...isso é o afeto catalizador. Isso que ela dizia que a gente tinha que praticar. Todos que trabalhassem na Casa Palmeiras tinham que praticar, porque isso é que iria fazer o processo andar. Você se despir da persona do psicólogo, do médico, do terapeuta e encontrar a pessoa face a face através do afeto.

NAPA: $O$ que seria o trabalho do monitor, além de ser um ser disponível? Tem mais algum elemento passível de descrição do que ele tinha que fazer lá? Além de estar disponível para o outro e para estimular o trabalho?

CHANG: Bom, o monitor tem uma responsabilidade de cuidar do ateliê, do material, da limpeza, da organização, mas tudo isso era feito fora do horário. Na hora de funcionamento, a preocupação dele eram as pessoas. Depois ele registrava tudo o que acontecia durante o dia, o funcionamento do ateliê: "fulano veio, pintou isso, pintou aquilo".

NAPA: Prontuário do paciente?

CHANG: Não, prontuário não. Você tinha uma espécie de registro do ateliê.

NAPA: Pastas?

CHANG: Pastas do ateliê. Diariamente, no final do dia, havia uma reunião entre os diversos ateliês onde eram trocadas as informações.

NAPA: Dos monitores?

CHANG: Dos monitores com a equipe técnica, coordenação. Aí nessas reuniões nós fazíamos uma avaliação e percebíamos, por exemplo, certos movimentos, pessoas que mudavam de ateliê:

- $\bigcirc$ que aconteceu? Reparou alguma mudança quando mudou de ateliê? Comentou alguma coisa?

Enfim, a gente procurava fazer uma espécie de avaliação do dia e isso, juntando dia após dia, você fica com uma avaliação do dia, da semana, do mês e ao longo do tempo. Uma vez por semana também nós fazíamos uma atividade de supervisão de caso, mas a palavra não é bem essa. Seria mais reunir todos os trabalhos de um determinado paciente. Todos os ateliês pintura, modelagem -, tudo que a pessoa tinha feito durante um certo período, isso era colocado e a gente fazia uma espécie de brainstorm. Ficávamos falando, conjecturando e tentando ver se conseguíamos descobrir algumas conexões sutis ali, entre os tipos de trabalho, mas também das atividades grupais. Primeiro eram as atividades do ateliê, depois tinha uma espécie de um lanche por volta de três e meia, que levava uma meia hora, as pessoas comiam, bebiam alguma coisa, conversavam e depois começava a atividade grupal. Cada dia era um dia diferente. Vamos dizer assim, tinha canto, tinha baile, tinha poesia, teatro e atividade física, que eu coordenava. 
Eu, como presidente, era também monitor da parte da atividade física às segundas-feiras. Eu tenho um outro lado, o lado chinês, eu sou taoísta também, eu pratico o tai chi chuan há muitos anos e, para mim, foi sempre muito importante essa questão da conexão do corpo com a psique. Eu sempre procuro conhecer mais, não só na minha prática pessoal, mas estimular também as pessoas quando eu vejo que elas necessitam fazer algum tipo de prática. Só que lá era um trabalho muito interessante porque você, obviamente, tinha que trabalhar com pessoas em um estado muitas vezes, emocionalmente, abalado, e vocês sabem que a respiração tem exatamente a ver com o nosso estado emocional. Quando está emocionado, você sempre respira no plexo solar. Dificilmente consegue descer a respiração até a região do baixo ventre. Agora, isso tem gradações, porque quando a pessoa está muito emocionada, a respiração começa a subir. Eu cheguei a presenciar casos de pessoas que respiravam aqui [no peito]. A respiração não conseguia descer mais, entendeu? A pessoa respirava com a boca aberta como se estivesse praticamente se afogando, pessoa em crise. que eu procurei fazer ali? Procurei fazer uns trabalhos de conscientização, você sentir a região aqui do baixo ventre, tentar respirar cada vez mais profundamente, fazer exercícios de dobra [coordenar movimentos corporais com respiração] para estimular, enfim, alguns exercícios do tai chi eu me propus a fazer e ficava observando. Foi um trabalho também de pesquisa: até que ponto a atividade física também tem, para o esquizofrênico, para o doente mental grave, um efeito terapêutico? Essa é uma linha de trabalho muito interessante, eu soube que na China existem grupos ligados ao tai chi que trabalham com doentes mentais dessa forma, fazendo exercícios espontâneos, exercícios de respiração, exercícios de movimentação, porque é como se a doença mental estivesse na psique e no corpo. Se ela está no corpo, talvez o corpo possa ser o início de um processo terapêutico coletivo. Isso é, por exemplo, uma questão ainda a ser pesquisada. É que nós aqui estamos ainda no início de uma coisa que eu acredito que tenha muito futuro. Para vocês terem uma ideia, existe na medicina chinesa um ponto específico que é o ponto do sonho.

NAPA: Onde que fica este ponto?

CHANG: Pois é, isso que é interessante. $\bigcirc$ problema é que, muitas vezes, você não precisa ativar o ponto, entendeu? A ideia é a seguinte: se você circula a sua energia, esse ponto vai ser ativado. Os taoístas dizem o seguinte: energia em movimento é saúde, energia parada é doença. Tivemos o encontro do mestre taoísta Liu Pai Lin com a doutora Nise. Conversa de mestres. Infelizmente, na época, não houve gravação, só tem notas. Agora, estou interessado em tecnologia, mas na época não tinha [interesse na área]. Então, foi um encontro maravilhoso porque nós pedimos para ele falar sobre psicologia do ponto de vista taoísta e pedimos para ela falar sobre taoísmo do ponto de vista psicológico. Por que o Jung era tão interessado em taoísmo? De todas as filosofias orientais, sem dúvida alguma, o taoísmo foi a que mais tinha a ver com ele. [Com a qual] ele sentia mais afinidade. De certa forma, a filosofia taoísta tinha muito a ver 
com a psicologia junguiana. Claro que cada uma dentro da sua cultura, mas, por que, por exemplo, não existiu psicologia lá na China? Porque as pessoas, quando tinham problemas, elas não iam, como nós aqui, ao psicólogo. Elas iam ao taoísta, entendeu? Contar seus problemas, contar seus sonhos, pedir para jogar / Ching. Tudo isso, vamos dizer, são formas de você integrar o inconsciente [ao] consciente. $\bigcirc$ que provavelmente é uma das causas das doenças é a cisão. Nesse encontro, ele [mestre Liu Pai Lin] procurou mostrar como as emoções fundamentais do ser humano estão dentro do nosso corpo, e como você trabalhando dentro do corpo, essas emoções não se tornam prejudiciais. Por exemplo, para os chineses, o rim é o órgão do medo. $\bigcirc$ fígado, da raiva. $\bigcirc$ coração, do amor. $\bigcirc$ pulmão, da tristeza. Cada órgão, na realidade, é conectado a uma emoção. Se você faz, de certa forma, essa circulação de energia, teoricamente, essas emoções nunca vão conseguir the dominar. Falando a nossa linguagem, sobrepujar o ego. A ideia que ele transmitiu foi mais ou menos essa. E a doutora Nise apresentou o seguinte: a ideia taoísta dos opostos, da necessidade da conjunção de yin e yang, é uma ideia fundamental da psicologia junguiana. Necessidade de você unir o inconsciente com o consciente e que isso pode ser feito de muitas formas. Pode ser feito através de uma pesquisa no próprio inconsciente, mas pode ser feita através de um trabalho artístico, de pinturas, de modelagem, de escrita, e também trabalhos corporais, de certa forma o que nós fazíamos na Casa das Palmeiras. Você vê, tudo isso é, na minha visão, é um enorme projeto de pesquisa. Um projeto de pesquisa que ainda está começando, uma coisa que ainda falta algum tempo, mas eu tenho esperanças que a gente consiga, com o tempo, ir reunindo cada vez mais elementos para começar a discutir mais esses assuntos.

NAPA: Eu queria fazer uma pergunta em relação ao dinamismo na Casa das Palmeiras. Você sabe que aqui em São Paulo os hospitais têm programações, de manhã, toma-se o café, tudo com horário e indicação ou contraindicação. Como é que era isso lá dentro do dinamismo da Casa?

CHANG: Lá na Casa, a gente nunca fez nenhuma indicação.

NAPA: Livre demanda.

CHANG: Livre demanda, mas no sentido da autocura. Ela acreditava profundamente que dentro de cada pessoa existia um elemento coletivo. Se você despertasse esse elemento coletivo, esse próprio elemento começaria a se movimentar por si só e iniciaria um processo de cura.

NAPA: Ou seja, a gente tem que tomar cuidado para não atrapalhar o movimento natural das coisas.

CHANG: Processo espontâneo, exatamente. E nesse sentido nós nunca saberemos como conduzir. De repente a Nise oferecia vários materiais, vários ateliês, deixava, espontaneamente, que o paciente escolhesse, porque ela acreditava que, naquele momento, a própria pessoa saberia identificar o que era melhor para ela se expressar. Qual o meio? Qual o material? E 
também, evidentemente, uma coisa sutil que se dava na relação afetiva com as pessoas, seja com o monitor, seja com colegas também.

Tem a propriedade do material, mas ela priorizava mais a relação, esse afeto catalisador e esse processo de autocura que há em cada um.

NAPA: Quando a Nise manda as fotos para o Jung, ele se interessa. Não sei se você tem essa informação, mas qual era a relação do Jung com as mandalas dos pacientes dele?

CHANG: Jung desde muito cedo teve uma conexão com o Oriente, primeiro com a ajuda da Toni Wolff, estudou filosofia hindu, principalmente. Toni Wolff era especialista na Índia. Depois, com o Richard Wilhelm, estudou a filosofia taoísta. Durante a vida toda dele, manteve contato com várias pessoas que estudavam filosofia, religião oriental. [Heinrich Robert] Zimmer, por exemplo, foi um deles. Ele percebeu, digamos assim, que tinha alguma coisa em relação à mandala muito cedo. Você lembra que nas memórias ele conta que, em 1917, ele estava na fronteira da Suíça com a Alemanha e ele começou a fazer um exercício de desenhar uma mandala, e ele percebia que toda vez que algo estava meio estranho, algum conteúdo inconsciente emergindo, ele não conseguia fechar a mandala. É uma coisa incrível.

NAPA: Isso foi em 1917?

CHANG: [19]17. Você vê, muito cedo ele já tinha um pouco essa noção de que a mandala era um elemento terapêutico.

Um outro ponto importante foi aquele trabalho da psicologia e alquimia, naquela sequência de sonhos do [Wolfgang Ernst] Pauli. Se você ver bem, naquela sequência de sonhos do Pauli está cheio de mandalas e ele aproveita esse material para desenvolver também a ideia dele de totalidade, do Self. A Nise mandou para ele os trabalhos em 1957.

Já tinha morrido a Toni Wolff, já tinha morrido a Ema [Jung], e ele já estava em um estado de deixar as coisas acontecerem, que, para os taoístas, é o último estágio da vida. Quando você deixa as coisas acontecerem sem julgar e sem opinar sobre nada. Neste momento veio o convite do [John] Freeman para a famosa entrevista da BBC.

Foi [19]57. Tudo aconteceu ali.

Então, teve a elaboração dos seus símbolos, foi nessa época que ele liberou a publicação dos seminários. Vocês sabiam que os seminários eram uma coisa fechada, não é? Só liberou nessa época, [19]56, [19]57. E a Nise surgiu exatamente nesse período mandando essas pinturas para ele. Ela disse, informalmente, que foi um grande ato de ousadia, porque ela tinha medo. Ela não mandou as pinturas, ela mandou foto das pinturas. Mas pelas fotos ele já percebeu que eram muito interessantes, aquele material todo, então ele a convidou para participar do "Segundo Congresso Internacional de Psiquiatria"; ela faria uma exposição desses quadros. Ela fez todo esse trabalho, emoldurar, preparar, selecionar e mandar. $\mathrm{Na}$ exposição da "Ocupação Nise" aparece, pela primeira vez, que eu vi pelo menos, em 
filme, o Jung abrindo a exposição, ela do lado e os dois fazendo comentários. Quer dizer, foi muito emocionante, porque mostra na realidade como o Jung valorizava o trabalho dela. Não era pouca coisa.

NAPA: E como ele usava as mandalas com os pacientes dele?

CHANG: Não tinha regra. Jung era uma pessoa muito intuitiva, ele percebia o potencial da pessoa. Por exemplo, a Barbara Hannah. Ela tinha formação em artes plásticas, só que ela não relacionava o que ela pintava com a terapia. Ele mostrou para ela que deveria continuar a pintar para o bem de sua saúde psíquica. Então, conforme a pessoa, ele estimulava uma coisa ou outra. Às vezes, era pintura, às vezes, era escrita.

NAPA: Eu queria fazer uma pergunta que me parece bem essencial. Você tem falado da espontaneidade e da liberdade que eram muito importantes para a Nise.

Quando nós pensamos no método que resguarda a espontaneidade, nós temos que imaginar que lugar que está a função da consciência e a intervenção diretiva do ego, que lugar ele ocupa? Acho que isso traz uma discussão bastante grande, porque eu não sei se os junguianos concordam muito bem em relação a isso. Então, eu gostaria que você comentasse esse assunto, do método da Nise, pensando talvez nas suas experiências, o quanto a experiência inteiramente espontânea pode ser considerada sempre curativa e em que medida a consciência e a diretividade podem colaborar ou não com o processo.

CHANG: Eu vou falar primeiro de uma coisa taoísta, porque no Tao Te Ching se diz assim: que o ideal da sabedoria é você se tornar de novo uma criança, com a espontaneidade, a liberdade de uma criança, mas não agir tolamente como criança. Não é virar criança, é recuperar a espontaneidade, aquela liberdade, aquela abertura do ser para o mundo, porque o problema todo é isso. Quando a gente não vive o fluxo, não vive o aqui e o agora, a gente, de certa forma, está em um outro tempo e outro espaço. A criança não, a criança está absolutamente aqui e agora. É essa espontaneidade a forma que o taoísta busca. Penso que pessoas como a Nise, como o Jung, valorizavam muito isso. Quer dizer, você pode dizer: "mas isso é intuição?" Pode ser também intuição, mas pode ser também um sentimento, pode ser uma imagem, pode ser um ato. É alguma coisa que vem, realmente, das profundezas, porque esse é o ato criativo. A consciência vai querer, depois do ato criativo, entender, o que é justo. Mas a consciência não pode vir antes do ato criativo, porque aí ela pode bloquear, ela pode fazer o papel do censor.

NAPA: Codirigir, pensando que pode haver um malefício nesse sentido.

CHANG: Pode. Se eu não me engano, no seminário do "Sonhos de Criança", Jung faz um exercício com o pessoal que é o seguinte: você pega um sonho, vamos pegar as imagens do sonho e vamos amplificar. Você pega imagem por imagem, amplifica, ele faz a pessoa falar, você pode 
amplificar o quanto você quiser. Quando a pessoa acabava de falar isso, ele falava assim:

- Agora me diga em uma frase o que significa esse sonho.

Era isso. Você amplifica, mas depois tem que ser capaz de simplificar. É um exercício, no caso, o que ele fazia era o seguinte: primeiro você faz um exercício de imaginação e, com isso, você deixa o inconsciente fluir, digamos assim, através das imagens. Só que isso é uma parte do processo, a outra parte é você entender com a consciência. Só que não é explicar isso e fazer uma teoria. Você tem que ser capaz de fazer isso e juntar em uma frase o que o sonho diz. É um exercício difícil, mas você fazendo isso, você está atendendo o outro lado da nossa natureza, que é a consciência.

NAPA: Qual é o papel da materialização do trabalho, na terapia ocupacional, a importância da materialização?

CHANG: No caso do pessoal da Casa das Palmeiras, a materialização significa trabalho. Então, você tem que pensar que a maior parte daquelas pessoas são socialmente inválidas, são desvalorizadas pela família, por todos; são chamados, muitas vezes, de incapazes ou de marginalizados, enfim. No entanto, quando você começa e faz alguma coisa, pode ser um traço, pode ser uma pequena imagem, você está movimentando a sua energia psíquica e transferindo do mundo interior para o material. Isso tem um efeito psicológico, um efeito energético, mas tem um efeito também social e de valorização perante a família. Então, uma coisa que a gente fazia de tempos em tempos era uma exposição dos trabalhos e chamávamos os familiares. Eles ficavam orgulhosos.

- Olha, mãe, o que eu fiz aqui. Olha, veja, meus trabalhos estão expostos.

Tiravam fotos, aquela coisa. $O$ indivíduo começa a se sentir mais capaz, mais forte e muitos deles, depois de algum tempo, conseguiam até enfrentar trabalhos, estudos, na vida social. Conseguiam sair de lá e enfrentar a realidade.

A doutora Nise com 10, 20 anos de imagens, de trabalhos de todos os clientes, o que ela descobre ali dentro? Ela descobre, muitas vezes, mitos inteiros que estão dentro das imagens. Por exemplo, no caso da Adelina, o mito da mulher flor que, na mitologia grega, é a Dafne. Foge de Apolo e implora para a "mãe-terra" ajudar. Esse motivo, a Adelina pintou anos e anos, flor, flor, flor. Parece que ela não conseguia sair do reino vegetal, mas houve um certo momento em que ela começa a pintar outros tipos de motivos. Começa a pintar animais, cachorro, gato.

NAPA: Interagiu com o ambiente.

CHANG: Interagiu com o ambiente porque a Nise, uma época, colocou um animal lá dentro. 
NAPA: Mas também tinha a história do gato dela, que ela tinha estrangulado o gato.

CHANG: Tinha estrangulado o gato, exatamente. De certa forma, quando você atinge essa camada mais profunda do inconsciente, nós estamos atingindo a camada curativa. Só que não basta você expressar, isso que é uma coisa difícil de explicar, mas eu vou tentar. Parece que é necessário que alguém olhe aquilo e reconheça.

NAPA: Testemunhe...

CHANG: Como se fosse uma consciência, mesmo que a consciência não esteja dentro da pessoa, mas existe uma consciência de que está acontecendo aquilo dentro da pessoa. Isso tem um efeito.

Independente da verbalização, é o testemunho, é uma presença. É o efeito catalisador.

NAPA: Não sei, isso me lembra um pouco autoimagem, porque esse papel terrível e dificílimo que é decodificar o bebê na sua solidão e na sua luta pela existência pós-útero, e que vai perdurar a vida inteira até a morte, deixando lacunas ao longo dessa existência. Parece que o terapeuta, de alguma maneira, pode validar essas lacunas que ficaram, essa solidão insuportável, existencial. Porque quando ele é assistido, seja em um sonho, seja em uma produção, uma compreensão maior, há uma saída desse lugar escuro e incompreensível.

CHANG: É. Os taoístas dizem o seguinte: antes de algo se manifestar na realidade, já existem muitos sinais. Eles se ligam nos sinais e essa é um pouco a ideia da sincronicidade. Antes de algo acontecer você já tem sinais do que está para acontecer. $\bigcirc$ que ocorre na sincronicidade parece que é eliminação do espaço-tempo. Eu me lembro de um caso de um rapaz, ele era muito rígido e muito convicto de certas coisas. Evidentemente ele estava em uma crise emocional porque a namorada não estava mais aceitando aquilo. Um dia eu estava comentando com meu supervisor, foi uma terçafeira, às 17h, sobre essa questão da necessidade dele demonstrar mais os sentimentos. Em uma relação afetiva é óbvio que isso é fundamental. Passou-se uns dias, ele veio e eu perguntei como é que estava a relação. Ele falou:

- Melhorou muito.

Falei:

- Você fez alguma coisa?

- Fiz. Terça-feira eu saí do trabalho, fui à floricultura e comprei um buquê de flores e levei para ela".

-Você se lembra da hora?

-17 horas. 
Isso é sincronicidade. $O$ observador afeta o resultado do experimento. Essa questão é muito importante, por que, na realidade, muitas vezes, nos casos, nós não temos a impressão que somos o observador, só a consciência? E é só deixar as coisas acontecerem? Os taoístas chamam isso de Wu wei, que quer dizer não ação. É a ação da não ação. A não ação não significa você não fazer nada, significa você observar e não falar nada.

NAPA: Mas tem uma ressonância, não é?

CHANG: Isso, é a ideia da ressonância. É isso que eu acho que é importante em um processo terapêutico porque, de certa forma, essa observação, esse olhar para a pessoa, para o indivíduo, tem um efeito também.

NAPA: $\bigcirc$ que você acha que transformou esse encontro e essa aproximação da Nise com o Jung, com von Franz? $\bigcirc$ que transformou nela, o que transformou no trabalho?

CHANG: É como se você sonhasse com uma coisa muito importante. De repente você visse em um sonho uma flor de ouro e, de repente, quando você guarda aquela imagem do sonho, ela é poderosa, mas se você está segurando a flor de ouro nas suas mãos, ela tem um poder. Isso é uma coisa diferente. Eu acho que, de certa forma, é um pouco isso que a Nise sentia em relação ao Jung. Um mestre que escreveu muita coisa, um mestre que a inspirava, um mestre que a orientava. A outra coisa é você estar na presença do mestre, porque estar na presença de um mestre evoca todo um mundo de sensações, de emoções, e que parece que, como os alquimistas dizem no estágio final, aquilo se materializa, se concretiza e aquilo se torna a pedra preciosa. Eu acho que foi fundamental esse encontro, foi fundamental porque, primeiro, ela o conheceu pessoalmente, foi reconhecida por ele. Segundo, ele indicou von Franz, porque ele já não tinha mais condições. Ele seria o terapeuta ideal para ela, mas ele já não atendia, já estava no final da vida, 82 anos. Ele indicou a pessoa que ele mais confiava, von Franz, que foi, de certa forma, a continuidade dele para ela. Isso é importante. Essa questão da concretização das coisas. Tem uma história taoísta que é assim:

"Um discípulo taoísta ouviu falar muito de um mestre:

- Mestre tal é maravilhoso.

Ele lê um monte de coisas e fala:

- Eu preciso conhecer esse mestre.

Ele vai lá, bate na porta, aparece o criado dizendo:

- Ele não está.

Volta outro dia:

- Não está.

Terceiro dia: 
- Ele não quer lhe ver, não está para ninguém.

O que o cara faz? Ele monta ali uma barraca em frente à casa dele. Passam-se mais de 10 dias. $\bigcirc$ mestre sai, finalmente, curioso, e pergunta para o cara:

- Prazer, o que você quer de mim, afinal?

Ele fala assim:

- Eu não quero nada, só quero estar perto de você."

Não é bonita essa história? É isso, ele só queria estar perto, não queria nada. Só queria poder ficar perto. Eu acho que isso é uma história típica. As pessoas que realmente são importantes em nossa vida, a gente quer estar perto. A gente não precisa conversar, fazer viagens e jantares.

No hexagrama 49 do I Ching, que é um hexagrama interessante, chama-se Caldeirão. É muito importante.

O 49 tem uma das linhas que diz assim: o mais importante é você conseguir alinhar a vida e o destino, porque assim que o fogo está debaixo do caldeirão, está tudo bem, porque estão alinhados. $\bigcirc$ fogo cozinha a comida que vai ser servida aos ancestrais ou aos deuses, não importa. Então, se você conseguir botar a sua vida e o seu destino alinhados, está tudo bem.

Eu acho que ela fez isto.

Isso é individual. Alinhar a vida e o destino. Com 16 anos ela foi ser médica lá na Bahia. Era a única mulher em 150 homens.

Dizia que sofreu muito preconceito. Teve um dia, não lembro exatamente em que matéria, não lembro bem porquê, mas o professor trouxe uma cobra. Ficou falando, pegou e deu para ela. $O$ pessoal deu gargalhada achando que ela ia titubear, dar um chilique. Ela pegou a cobra na maior frieza, passou a mão, e passou adiante.

NAPA: Como era o caminho dela no trabalho com o próprio inconsciente?

CHANG: Ela se autodenominava uma psiquiatra rebelde. Ela nunca seguiu a linha das convenções. O filme "Nise" mostra bem isso. Eu acho que, no momento em que ela volta do exílio, em [19]46, que ela se autoexilou por causa do governo Vargas, ela volta ao hospital Dom Pedro II e lá querem que ela seja uma médica convencional, que dê eletrochoques, aquelas coisas, e ela se recusa. $O$ diretor do hospital oferece para ela o cargo mais desvalorizado, que ninguém queria, que era da terapêutica ocupacional. Ali, naquele momento que eu acho que ela começa, realmente, a alinhar as coisas, porque ela pediu só uma coisa:

- Eu topo, mas eu quero liberdade.

Ele falou:

- Pode fazer o que você quiser, só tem dois funcionários, está tudo abandonado. 
Aí ela foi começando a construir aos poucos, chamando as pessoas para trabalhar. Uma das primeiras pessoas que ela chamou para trabalhar no ateliê de pintura foi o Almir Mavignier, que hoje é um artista conceituado [Almir faleceu algum tempo depois desta entrevista]. A partir daquele momento, o trabalho dela na psiquiatria começou a adquirir um tom individual, pessoal. Ela pode, naquele momento, começar a desenvolver o processo criativo.

NAPA: Ela precisou respeitar os limites dela, sua natureza.

CHANG: Exatamente, aos princípios.

NAPA: $E$ as fotos dela estão lá como se ela tivesse mandado hoje para Zurique. É impressionante essa questão do cuidado, do respeito. Não está lá jogado em qualquer lugar, está perfeitamente guardado.

Muito obrigada.

CHANG: Obrigado mesmo pela oportunidade.

\section{Referências}

Silveira, N. M. (1971). Jung, vida e obra. Rio de Janeiro: J. Alvaro.

Berliner, R. (Diretor). (2016). Nise: o coração da loucura. $109 \mathrm{~min}$. http://www.adorocinema.com/filmes/filme-240724/

Ocupação Nise da Silveira. (2017, 25 novembro a 2018, 28 de janeiro). São Paulo.

Jung, C. G. (1959). Face to face (Entrevista a John Freeman). Zurich: BBC.

Minicurrículos: Cristiane Adamo - Analista membro do Instituto Junguiano de São Paulo - IJUSP e da Associação Junguiana do Brasil - AJB, filiada à International Association for Analytical Psychology - IAAP. Psicóloga. Membro do Departamento de Arte da AJB e do Núcleo de Artes e Psicologia Analítica do IJUSP (NAPA/IJUSP). São Paulo, SP, Brasil. E-mail:

Denis Canal Mendes - Analista membro do IJUSP e da AJB, filiada à IAAP. Especialista em Saúde Mental - SES e pesquisador do Núcleo de Estudos Junguiano da Pontifícia Universidade Católica de São Paulo (PUC-SP). Psicólogo. Membro do Departamento de Arte da AJB e do NAPA/IJUSP. São Paulo, SP, Brasil. E-mail:

Irene Gaeta - Analista membro do IJUSP e da AJB, filiada à IAAP. Doutora e mestre pela PUC-SP. Coordenadora da Pós-Graduação Psicoterapia Junguiana da Universidade Paulista (UNIP). Psicóloga. Coordenadora do Departamento de Arte da AJB e do NAPA/IJUSP. São Paulo, SP, Brasil. Email: estudosjunguianos.irenegaeta@gmail.com 
Paola V. Vergueiro - Analista em formação pelo IJUSP. Doutora em Psicologia Clínica pela PUC-SP. Psicóloga. Membro do Departamento de Arte da AJB e do NAPA/IJUSP. São Paulo, SP, Brasil. E-mail: paola.vv@hotmail.com

Paula Daré - Analista membro do IJUSP e da AJB, filiada à IAAP. Especialista em Cinesiologia pelo Instituto Sedes Sapientiae. Psicóloga. Membro do Departamento de Arte da AJB e do NAPA/IJUSP. São Paulo, SP, Brasil. Email: pauladare@hotmail.com

Patrícia Pires de Campos - Analista membro do IJUSP e da AJB, filiada à IAAP. Especialista em Jung e Corpo pelo Instituto Sedes Sapientiae. Psicóloga. Membro do Departamento de Arte da AJB e do NAPA/IJUSP. São Paulo, SP, Brasil. E-mail:

Silvana Parisi - Analista em formação pelo IJUSP e da AJB, filiada à IAAP. Doutora e mestre pelo Instituto de Psicologia da Universidade de São Paulo. Professora no Instituto Sedes Sapientiae e na Pós-Graduação da UNIP/SP. Psicóloga. Membro do Departamento de Arte da AJB e do NAPA/IJUSP. São Paulo, SP, Brasil. E-mail: silparisi@gmail.com 